\title{
Cortisol Hormone Concentration and Meat Quality of Beef Cattle Stunned by Captive Bolt Stun Gun before Slaughtering
}

\author{
K. Maghfiroh ${ }^{\mathrm{a} *}$, H. Latif ${ }^{\mathrm{b}}$, \& K. Santoso ${ }^{\mathrm{c}}$ \\ aVeterinary Public Health, Faculty of Veterinary Medicine, Bogor Agricultural University \\ ${ }^{b}$ Department of Animal Diseases and Veterinary Public Health, Faculty of Veterinary Medicine, \\ Bogor Agricultural University \\ 'Department of Anatomy, Physiology and Pharmacology, Faculty of Veterinary Medicine, \\ Bogor Agricultural University \\ Jln. Agatis, Kampus IPB Darmaga, Bogor 16680, Indonesia \\ (Received 23-06-2014; Reviewed 18-08-2014; Accepted 30-09-2014)
}

\begin{abstract}
This study was aimed to describe cortisol hormone concentration and meat quality which were produced in beef cattle stunned with captive bolt stun gun before slaughtering. Blood and meat samples were taken from Brahman cross steers $(n=11)$ in two abattoirs located in West Java and Banten. Blood samples were collected immediately after slaughtering. Cortisol hormone concentration in the serum was measured by using radioimmunoassay (RIA). The descriptive, correlation, and regression analyses were used to interprete data. Meat quality assessment was based on $\mathrm{pH}$, cooking loss, and complete drainage of blood. The average of cortisol hormone concentration was $26.59 \mathrm{ng} / \mathrm{mL}$. Meat $\mathrm{pH}$ at $1 \mathrm{~h}$ postmortem and $24 \mathrm{~h}$ postmortem were 6.65 and 6.21, respectively. Meat cooking loss was $26.77 \%$. Blood drainage in meat samples of each cattle showed complete drainage. There was a significant correlation $(\mathrm{P}<0.05)$ between cortisol concentrations and $\mathrm{pH}$ at 1 hour postmortem as well as cortisol concentration and cooking loss. There was no significant correlation between $\mathrm{pH}$ at $24 \mathrm{~h}$ postmortem and cooking loss. Cattle was stunned with a captive bolt stun gun before slaughtering produced meat with complete blood drainage but had high cortisol hormone concentration and $\mathrm{pH}$ ultimate.
\end{abstract}

Key words: cortisol, quality of meat, stunning, captive bolt stun gun

\section{ABSTRAK}

Penelitian ini bertujuan untuk mendapatkan gambaran konsentrasi hormon kortisol dan kualitas daging yang dihasilkan pada sapi yang dipingsankan dengan captive bolt stun gun sebelum disembelih. Sampel darah dan daging diambil dari sapi Brahman cross steer $(n=11)$ di dua RPH di Provinsi Jawa Barat dan Banten. Darah yang memancar setelah penyembelihan ditampung dan diambil serumnya selanjutnya konsentrasi hormon kortisol diukur menggunakan metode radioimmunoassay (RIA). Pengukuran kualitas daging dilakukan dengan mengukur nilai $\mathrm{pH}$, cooking loss, dan kesempurnaan pengeluaran darah. Analisis deskriptif, korelasi, dan regresi digunakan dalam penelitian ini. Nilai rata-rata konsentrasi hormon kortisol adalah $26,59 \mathrm{ng} / \mathrm{ml}$. Nilai rata-rata $\mathrm{pH}$ jam ke-1 dan ke-24 secara berurutan, yaitu 6,65 dan 6,21. Nilai rata-rata cooking loss adalah $26,77 \%$. Pemeriksaan kesempurnaan pengeluaran darah menunjukkan adanya pengeluaran darah yang sempurna. Terdapat korelasi bermakna $(P<0,05)$ antara konsentrasi hormon kortisol dengan nilai $\mathrm{pH}$ jam ke-1 dan konsentrasi hormon kortisol dengan cooking loss. Tidak terdapat korelasi bermakna antara nilai $\mathrm{pH}$ jam ke-24 dengan cooking loss. Dengan demikian dapat disimpulkan bahwa sapi yang dipingsankan dengan captive bolt stun gun sebelum penyembelihan memiliki daging dengan pengeluaran darah yang sempurna namun konsentrasi hormon kortisol dan $\mathrm{pH}$ ultimate yang tinggi.

Kata kunci: kortisol, kualitas daging, pemingsanan, captive bolt stun gun

\footnotetext{
${ }^{*}$ Corresponding author:

E-mail: maghfiroh.karunia@gmail.com
} 


\section{INTRODUCTION}

Slaughtering is one of the steps which determine meat quality. According to the OIE (2008), there are two slaughter methods including slaughter with prior stunning and slaughter without prior stunning. Slaughter method which will be used should consider animal welfare aspects.

Captive bolt stunning is one of stunning techniques prior to slaughtering that are considered to fulfill animal welfare aspects and minimize stress in animals. This technique has been used by several abattoirs in Indonesia and has been considered to be efficient in slaughtering a large number of cattle. However, it is suspected to have a disadvantage in which blood drainage is not complete that affect meat quality.

Stress is physiological mechanisms of animal to respond to stress stimuli with minimum alteration in homeostasis (Mudron et al., 2005). According to Okeudo \& Moss (2005), stress can be differentiated into physical and psychological stress. Pre-slaughter stress can stimulate the release of cortisol hormone. Cortisol is released whether in acute or chronic stress and functioned to supply energy reserves for each individual through the conversion of glycogen into energy (Bayazit 2009).

Based on research by Colditz et al. (2006), stress can increase cortisol concentration in blood and depletion of glycogen reserves in muscles. This can lead to a decrease in postmortem lactic acid production and cause meat $\mathrm{pH}$ remain high (Mounier et al. 2006). Stress can also have an adverse effect on the water-holding capacity (Ekiz et al. 2012). This study was aimed to determine cortisol concentration and meat quality in cattle stunned by captive bolt stun gun before slaughtering. The study about the relationship between the cortisol hormone concentration and meat quality by slaughtering with prior stunning in Indonesia has not been done. Therefore, this research was aimed to provide an overview of the cortisol hormone concentration and meat quality in cattle stunned by captive bolt stun gun before being slaughtered.

\section{MATERIALS AND METHODS}

\section{Materials}

Materials used in this study were blood and meat samples taken from 11 castrated Brahman cross cattle (steers), which were stunned before slaughtering at two abattoirs in West Java and Banten Provinces from September 2013 to March 2014. Purposive sampling method was used in this study. It is a type of non-probability sampling technique that allows researchers to choose the best incidence to answer the research question(s) and to meet the objectives of the researchers (Saunders et al. 2009).

Blood samples were collected by using tubes after slaughtering and kept for about 4-5 h at room temperature during transport. Then blood samples were put in the refrigerator followed by centrifugation. Blood serum was then taken for further testing. Meat samples (Musculus Longissimus dorsi) were taken in the amount of $500 \mathrm{~g}$ from each cattle to determine meat quality.
Other materials used were radioimmunoassay (RIA) kit (Institutes of Isotopes Co., Ltd, RK-240CT) and automatic gamma counter A 6.24 (Austria).

\section{Cortisol Hormone Concentration Measurement Using Radioimmunoassay (RIA)}

Based on the modification of method by Okuedo \& Moss (2005), serum cortisol was measured by using [I- 125] RIA kit (per vial containing $<260 \mathrm{kBq}{ }^{125}$ I-Cortisol in buffer with $0.1 \% \mathrm{NaN}_{3}$ ). Reagents and samples were equilibrated at room temperature before being used (minimum for an hour). Coated tubes were labeled and prepared in duplicate for each standard (S1-S6), control (C) and samples (Sx). Uncoated labeled test tube was used for total count (T). All reagents and samples were homogenized to avoid foaming. Then $10 \mathrm{~mL}$ of standard, control and sample were added into the properly labeled tubes. It was followed by adding $500 \mathrm{~mL}$ of tracer into each tube. Then $500 \mathrm{~mL}$ of antiserum was added into each tube except $\mathrm{T}$. Test tube rack was fixed onto the shaker plate. All tubes were sealed by plastic foil. Shaker was turned on and adjusted in an adequate speed so that the liquid in each tube constantly rotating. Then tubes were incubated for $2 \mathrm{~h}$ at room temperature. Supernatant was aspirated from all tubes. Then the tube rack was placed in upside down position on an absorbent paper for $2 \mathrm{~min}$. Each tube was counted for at least $60 \mathrm{sec}$ in a gamma counter. Cortisol concentrations of each sample were then calculated.

\section{Meat pH Measurement}

The modification has been made from Honikel's method (1998). Meat samples were stored in plastic bags at room temperature $\left(25-34{ }^{\circ} \mathrm{C}\right)$ before measurements. Meat $\mathrm{pH}$ was measured at $1 \mathrm{~h}$ postmortem and $24 \mathrm{~h}$ postmortem, and were kept cold between first and second measurements. The $\mathrm{pH}$ meter was calibrated with standard solutions ( $\mathrm{pH} 4$ and $\mathrm{pH}$ 7) before the measurements, and after each measurement, the glass electrode of $\mathrm{pH}$ meter was rinsed with distilled water and dried with wipes.

\section{Cooking Loss Measurement}

The modification has been made from Salakova et al. (2009). The modification based on the internal temperature. Cooking loss was measured in three steps: samples weighing, cooking, and the measurement. Meat samples were weighed ( $a$ gram) and then put into a heat resistant plastic bag. The samples in heat resistant plastic bag were heated in the water bath at $75{ }^{\circ} \mathrm{C}$ for $50 \mathrm{~min}$ and then weighed again ( $b$ gram). Then meat samples were removed from water bath and cooled at a temperature of $1-5^{\circ} \mathrm{C}$. Cooking loss was determined by using the following formula:

$\%$ cooking loss $=[(a-b) / a] \times 100 \%$

Noted: a: The weight of the meat before cooking (g); $\mathrm{b}$ : The weight of the meat after cooking (g). 


\section{Determination of Complete Blood Drainage}

Meat extracts were made by cutting $6 \mathrm{~g}$ of meat into small size and then put into $14 \mathrm{~mL}$ of distilled water in the Erlenmeyer flask. The extracts were kept for $15 \mathrm{~min}$ and filtered. Then $0.7 \mathrm{~mL}$ of filtrate was taken and put into a test tube. One drop of each malachite green and $3 \% \mathrm{H}_{2} \mathrm{O}_{2}$ were added into the test tube. The mixtures were kept for $20 \mathrm{~min}$ at room temperature and color reaction formed were observed. The formation of blue color indicated the complete drainage of blood (Lukman \& Purnawarman, 2013).

\section{Data Analysis}

The data were analyzed using descriptive, correlatiion, and regression analyses according to Dahlan (2011). The data were presented descriptively in the form of tables describing cortisol concentration and criteria of meat quality. The correlation analysis were including correlation between cortisol concentration and $\mathrm{pH}$, cortisol concentration and cooking loss, as well as $\mathrm{pH}$ and cooking loss.

\section{RESULTS AND DISCUSSION}

\section{Cortisol Concentration}

Cortisol concentration in this study was measured by using radioimmunoassay (RIA) with $1.05 \mathrm{ng} / \mathrm{mL}$ of limit detection. Typical standard curve of RIA method for cortisol measurement is presented in Figure 1. This curve was used to determine cortisol concentration which was previously undetected of any samples by interpolation of standard curve.

Cortisol concentration of beef cattle measured in this study was $26.58 \pm 16.60 \mathrm{ng} / \mathrm{mL}$ (Table 1 ). It was higher than that reported by Mounier et al. (2006) in which average blood cortisol concentration during slaughtering was approximately $21 \mathrm{ng} / \mathrm{mL}$. According to Ewbank et al.

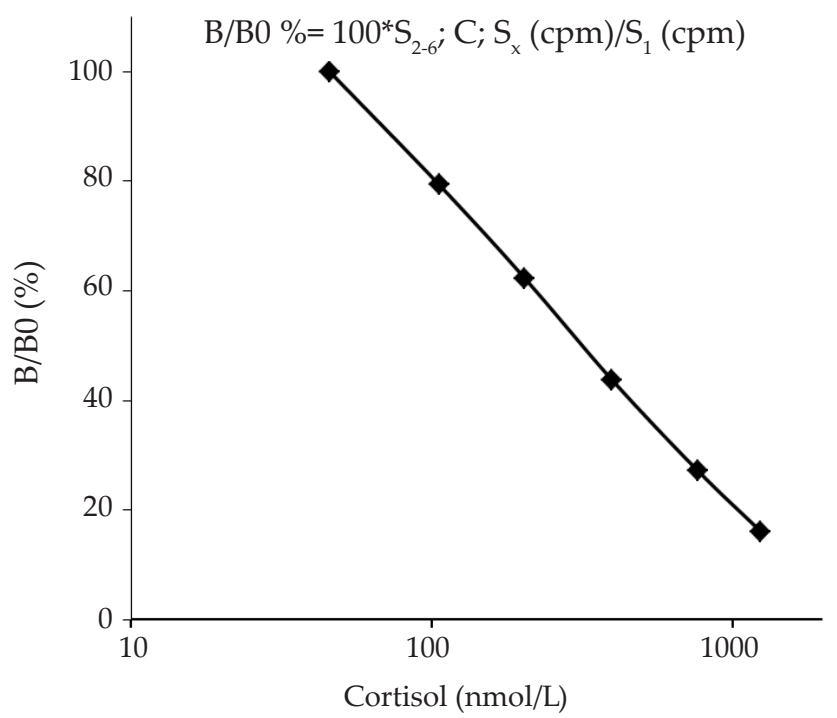

Figure 1. Typical standard curve of RIA kit for cortisol measurement $(1 \mathrm{nmol} / \mathrm{L}=0.362 \mathrm{ng} / \mathrm{mL})$
(1992), cortisol concentration of well-handled beef cattle is $24 \mathrm{ng} / \mathrm{mL}$. High value of cortisol concentration in this study presumably due to animal stress. It was presumed that the cattle did not only experience stress during slaughtering, but also prior to slaughtering which could be caused by poor handling at lairage, in the gang way, or when animals were entering the stunning box as well as poorly trained stunner operator.

According to Grandin (2007), stress prior to slaughtering can be differentiated into two types including physical and psychological stresses. Physical stress can be caused by high ambient temperatures, vehicle shake, noise and density (Chulayo et al., 2012), slippery floor (Grandin 2007), lack of food and water as well as loading and unloading from the truck (Mareko 2005). According to Maheswari et al. (2013), transportation can increase cortisol level on day-1 approximately 2-2.5 ng/dL when the animals just arrived to the location even just short-term transportation.

Psychological stress can be caused by group separation, mixing with an unknown group, and new environment (Adziety, 2011). Improper stunning can also be stressful in which stunning tools do not functioned properly and/or stunner operator is poorly trained (Mareko, 2005).

Cortisol concentration quite varied among individuals in this study. Stunning and slaughtering of each cattle were conducted through the relatively same procedure. Hence the variation of cortisol concentration among individuals was suspected to be influenced by physiological and adaptive capabilities to stress via homeostasis in each individual. According to Soeparno (2005), stress response depends on capability of each individual to adapt via homeostasis mechanism. There are variation of responses among breeds and species. High variation of behavior also can be discovered among individuals belong to the same species (derived from the same breed and environmental conditions) (Miranda-de la Lama et al., 2011).

\section{Meat $\mathrm{pH}$}

Meat $\mathrm{pH}$ is one of those characteristics which can describe meat quality. The result of descriptive analysis for meat $\mathrm{pH}$ in beef cattle stunned by captive bolt stun gun before slaughtering is shown in Table 1.

This $\mathrm{pH}$ value revealed that meat ultimate $\mathrm{pH}$ ( $\mathrm{pHu}$ ) slightly decreased which was presumably caused by low glycogen reserves before slaughtering. Low glycogen reserves could be caused by lack of resting time

Table 1. Cortisol concentration, meat $\mathrm{pH}$, and cooking loss in beef cattle stunned by captive bolt stun gun before slaughtering $(n=11)$

\begin{tabular}{lrcc}
\hline & Average \pm sd & Minimum & Maximum \\
\hline Cortisol concentration $(\mathrm{ng} / \mathrm{mL})$ & $26.58 \pm 16.60$ & 4.86 & 50.75 \\
Meat $\mathrm{pH}$ & & & \\
$\quad$ 1 h postmortem & $6.64 \pm 0.31$ & 6.02 & 7.01 \\
$\quad 24$ h postmortem & $6.21 \pm 0.23$ & 5.78 & 6.55 \\
Cooking loss $(\%)$ & $26.77 \pm 5.53$ & 17.00 & 36.78 \\
\hline
\end{tabular}


for the cattle after being transported from farms of origin as well as poor handling in temporary shelter.

Beef that has $\mathrm{pH}_{\mathrm{u}}>6.0$ after slaughtering indicates a change in the quality of meat. The meat has a dark red color (dark firm and dry/DFD) (Gruber et al., 2010), a high level of tenderness variation, and low palatability (Mach et al., 2008).

According to Hambrecth et al. (2005), short lairage (holding time) duration will cause $\mathrm{pH}$ remains high compared to the longer duration. Resting period for eating and drinking is needed by the cattle to restore their energies after transportation. The standard of lairage time duration for a cattle after transportation is 12-24 h (Ferguson et al., 2007).

\section{Cooking Loss}

Cooking loss is weight lost percentage of meat due to cooking process. The average percentage of cooking loss measured in this study was $26.77 \pm 5.53 \%$ (Table 1). According to Soeparno (2005), cooking loss commonly ranged between $15 \%-54.5 \%$. Thus cooking loss measured in this study was within normal range. Variation in cooking loss can be caused by a number of factors including differences in storage period, cooking methods, cooking temperature, cooking time, $\mathrm{pH}$ and marbling (Yu et al., 2005).

The decrease of cooking loss due to the length of storage period is estimated to be the result of enzymatic reactions by endogenous enzymes such as collagenase, which destroys myofibrillar proteins and connective tissues (Bruce et al., 2003). Cooking method has the most important effect on cooking loss with several influencing variables consist of meat surface, heat transfer method, and internal temperature (Panea et al., 2008). Soeparno (2005) reported that body area from which the muscle is sampled also influences cooking loss.

\section{Complete Drainage of Blood}

Blood drainage is an important factor in slaughtering and also the main requirements of meat to be consumed as well as to maintain its quality. Examination of blood drainage in all meat samples showed complete drainage which were indicated by blue color. This was presumably because the cattle were slaughtered properly and in healthy condition so that no hemoglobin $(\mathrm{Hb})$ remained inside the meat.

Mohamed \& Mohamed (2012) explained that the presence of blood in carcass influences its aroma and shelf life of the meat. The physical state of the animal before slaughtering, stunning method, interval between stunning and bleeding, all diseases which debilitate the circulatory system, feverish, acute diseases promote generalized vasodilatation are several factors which responsible for bleeding efficiency (Petty et al., 1994). Residual blood in muscles with $\mathrm{pH}$ of about 7 , leads to the increase of muscle $\mathrm{pH}$ and consequently meat Aw (water activity) raises. Thus, result in proliferation of spoilage microorganisms in which cause spoilage of the meat (Hajmohammadi et al., 2014).

\section{Correlation between Cortisol Concentration and $\mathrm{pH}$}

There was a significant correlation $(\mathrm{P}<0.05)$ between cortisol concentration and $\mathrm{pH}$ at $1 \mathrm{~h}$ postmortem, but no significant correlation between cortisol concentration and $\mathrm{pH}$ at $24 \mathrm{~h}$ postmortem. It can be caused by high cortisol concentration values but $\mathrm{pH}$ at $24 \mathrm{~h}$ postmortem low because the amount of lactic acid increased. Cortisol concentration was positively correlated with $\mathrm{pH}$ at both stages which means that the higher cortisol concentration, the higher $\mathrm{pH}$ values. The result in accordance with that reported by Okuedo \& Moss (2005) in which cortisol concentration was positively correlated with $\mathrm{pH}$ at 24 hours postmortem. The result of correlation analysis between cortisol hormone concentration and $\mathrm{pH}$ value from beef cattle stunned by a captive bolt stun gun before slaughter is shown in Table 2 .

Stress may increase blood cortisol concentration as well as depletion of glycogen in the muscles (Colditz et al., 2006). This causes the formation of lactic acid decreases and postmortem meat $\mathrm{pH}$ remains high (Mounier et al., 2006). Weglarz (2010) suggested that stress and energy loss prior to slaughter can lead to reduced muscle glycogen reserves resulting in the insufficient formation of lactic acid in postmortem stage.

\section{Correlation between Cortisol Concentration and Cooking Loss}

There was a significant correlation between cortisol concentration and cooking loss $(\mathrm{P}<0.05)$. It means that the higher cortisol concentration, the higher cooking loss. The result of correlation analysis between cortisol hormone concentration and cooking loss from beef cattle stunned by a captive bolt stun gun before slaughtering is shown in Table 2.

According to Gregory (1998), cortisol is a corticosteroid hormone which functioned to stimulate proteolysis. Postmortem proteolysis is one of important factors which influence water holding capacity (WHC) of the meat. This process includes calpain system, calpastatin, and protein oxidation. Calpain system is the main factor which assure postmortem proteolysis properly occur before and after rigor state (Huff- Lonergan \& Lonergan, 2005).

Table 2. Correlation analysis between cortisol hormone concentration, $\mathrm{pH}$ value, and cooking loss

\begin{tabular}{lcc}
\hline & \multicolumn{2}{c}{ Cortisol hormone concentration } \\
\hline $\mathrm{pH}$ 1 h postmortem & $\mathrm{r}$ & 0.71 \\
& $p$ & 0.02 \\
$\mathrm{pH}$ 24 h postmortem & $\mathrm{n}$ & 11 \\
& $\mathrm{r}$ & 0.20 \\
Cooking loss & $p$ & 0.56 \\
& $\mathrm{n}$ & 11 \\
& $\mathrm{r}$ & 0.66 \\
& $p$ & 0.03 \\
\hline
\end{tabular}

Note: $\mathrm{r}=$ correlation; $\mathrm{p}=$ significancy; $\mathrm{n}=$ number of samples. 


\section{Correlation between $\mathrm{pH}$ and Cooking Loss}

Cooking loss did not have a significant correlation with $\mathrm{pH}$ at $24 \mathrm{~h}$ postmortem. High $\mathrm{pH}$ may increase WHC and decrease cooking loss (Weglarz, 2010). The result of this study showed that high $\mathrm{pH}$ did not always be followed by low cooking loss. It was due to some complex factors which influenced WHC, thus influenced cooking loss. Those factors presumably consisted of physical/biochemical factors of muscles as well as postmortem proteolysis. The high $\mathrm{pH}_{\mathrm{u}}$ of $\mathrm{M}$. Longissimus dorsi was presumed not to be strong enough to maintain WHC due to postmortem changes in muscles. The result of correlation analysis between cooking loss and $\mathrm{pH}$ value from beef cattle stunned by a captive bolt stun gun before slaughtering is shown in Table 3 .

Table 3. Correlation analysis between cooking loss and $\mathrm{pH}$ value

\begin{tabular}{llc}
\hline & \multicolumn{2}{c}{ Cooking loss } \\
\hline $\mathrm{pH}$ 24 h postmortem & $\mathrm{r}$ & 0.43 \\
& $p$ & 0.19 \\
$\mathrm{n}$ & 11 \\
\hline
\end{tabular}

Note: $\mathrm{r}=$ correlation; $\mathrm{p}=$ significancy; $\mathrm{n}=$ number of samples.

Physical/biochemical factors in muscles that affect WHC are net charge effects and steric effects. Net charge effects can be reached in isoelectric point of meat $\mathrm{pH}$. The net charge of the protein is zero, meaning the numbers of positive and negative charges on the protein are essentially equal and attracted to each other, result in a reduction in the amount of water that can be attracted by the protein. The end result of net charge effects is a reduction of space within the myofibril. The second factor that affect WHC is steric effect. Steric effects is also reducing the available space for water to reside. This occur as muscle goes into rigor in which cross-bridges are formed between the thick and thin filaments of myofibrils (Huff-Lonergan \& Lonergan, 2005).

\section{CONCLUSION}

Cattle stunned with a captive bolt stun gun before slaughtering had a high cortisol hormone concentration $(26.59 \pm 16.61 \mathrm{ng} / \mathrm{mL})$ and produced meat with complete blood drainage. High cortisol values resulted in high $\mathrm{pH}$ but cooking loss values were still within the normal range.

\section{REFERENCES}

Aberle, E. D., J. C. Forrest, D. E. Gerrard, E. W. Mills, H. B. Hedrick, M. D. Judge, R. A. Merkel. 2001. Principles of Meat Science. $4^{\text {th }}$ edition. Dubuque Iowa, Kendal/Hunt.

Adzitey, F. 2011. Minireview effect of preslaughter animal handling on carcass and meat quality. Int. Food Res. J. 18:485491.

Bayazit, V. 2009. Evaluation of cortisol and stress in captive animals. J. Aus. Basic. Appl. Sci. 3:1022-1031.
Bruce, H. L., J. L. Stark, \& S. L. Beilken. 2003. The effect of finishing diet and post mortem ageing on the quality of M. longissimus thoracis of the electrically stimulated Brahman steer carcasses. Meat Sci. 67:261-268. http://dx.doi. org/10.1016/j.meatsci.2003.10.014

Chulayo, A. Y., O. Tada, \& V. Muchenje. 2012. Research on preslaughter stress and meat quality: A review of challenges faced under practical conditions. Appl. Anim. Husb. Rural Develop. 5:1-6.

Colditz, I. G., D. L. Watson, R. Kilgour, D. M. Ferguson, C. Prideaux, J. Ruby, P. D. Kirkland, \& K. Sullivan. 2006. Impact of animal health and welfare research within the CRC for Cattle and Beef Quality on Australian beef production. Aust. J. Exp. Agr. 46:233-244. http://dx.doi. org/10.1071/EA05211

Dahlan, S. M. 2011. Statistic for Health and Medicine. $5^{\text {th }}$ ed. Salemba Medika, Jakarta.

Ekiz, B., E. E. Ekiz, O. Kocak, H. Yalcintan, \& A. Yilmaz. 2012. Effect of pre-slaughter management regarding transportation and time in lairage on certain stress parameters, carcass and meat quality characteristics in Kivircik. Meat. Sci. 90:967-976. http://dx.doi.org/10.1016/j.meatsci.2011.11.042

Ewbank, R., M. J. Parker, \& C. W. Mason. 1992. Reactions of cattle to head-restrain at stunning: a practical dilemma. Anim. Welfare. 1:55-64.

Ferguson, D. M., F. D. Shaw, \& J. L. Stark. 2007. Effect of reduced lairage duration on beef quality. Aus. J. Exp. Agric. 47:770-773. http://dx.doi.org/10.1071/EA05212

Grandin, T. 2007. Handling and Welfare of Livestock in Slaughter Plants. CABI, USA.

Gregory, N. G. 1998. Animal Welfare and Meat Science. Cambridge University Pr, Cambridge.

Gruber, S. L., J. D. Tatum, T. E. Engle, P. L. Chapman, K. E. Belk, \& G. C. Smith. 2010. Relationship of behavioral and physiological symptoms of preslaughter stress to beef longissimus muscle tenderness. J. Anim. Sci. 88:1148-1159. http://dx.doi.org/10.2527/jas.2009-2183

Hajimohammadi, B., M. H. Ehrampoush, \& B. Hajimohammadi. 2014. Theories about effects of Islamic slaughter laws on meat hygiene. Health Scope. 2:14376.

Hambrecht, E., J. J Eissen, D. J. Newman, C. H. M. Smits, M. W. A. Verstegen, \& L. A. Den Hartog. 2005. Preslaughter handling effects on pork quality and glycolytic potential in two muscles differing in fiber type composition. J. Anim. Sci. 83:900-907.

Honikel, K. O. 1998. Reference methods for assessment of physical characteristic of meat. Meat Sci. 49:447-457. http:// dx.doi.org/10.1016/S0309-1740(98)00034-5

Huff-Lonergan, E., \& S. M. Lonergan. 2005. Mechanism of water holding capacity of meat: The role of postmortem biochemical and structural changes. Meat Sci. 71:194-204. http://dx.doi.org/10.1016/j.meatsci.2005.04.022

Lukman, D. W., \& T. Purnawarman. 2013. Meat Examination. In: Lukman DW, Purnawarman T (Ed). Guidance for Meat Hygine Examination. Bogor, FKH IPB. p.45.

Mach, N., A. Bach, A. Velarde, \& M. Devant. 2008. Association between animal, transportation, slaughterhouse practices, and meat $\mathrm{pH}$ in beef. Meat Sci. 78:232. http://dx.doi. org/10.1016/j.meatsci.2007.06.021

Maheshwari, H., Yulnawati, A. Esfandiari, Andriyanto, M. D. Andriani, \& A. Khovifah. 2013. Profiles of cortisol, triiodothyronine, thyroxine and neutrophil/lymphocyte ratio as stress indicators in swamp buffaloes 15 days post-transportation. Med. Pet. 36:106-112. http://dx.doi.org/10.5398/ medpet.2013.36.2.106

Mareko, M. H. D. 2005. Effects of pre-slaughter stress on carcass/meat quality: Implication for Botswana. J. Anim. Vet. Adv. 4:761-767. 
Miranda-de la Lama, G. C., W. S. Sepúlveda, H. H. Montaldo, G. A. María, \& F. Galindo. 2011. Social strategies associated with identify profiles in dairy goats. Appl. Anim. Behav. Sci. 134:48-55. http://dx.doi.org/10.1016/ j.applanim.2011.06.004

Mohamed, B., \& I. Mohamed. 2012. The effects of residual blood of carcasses on poultry technological quality. Food Nut. Sci. 3:1382-1386. http://dx.doi.org/10.4236/fns.2012.310181

Mounier, L., H. Dubroeucq, S. Andanson, \& I. Veissier. 2006. Variations in meat $\mathrm{pH}$ of beef bulls in relation to conditions of transfer to slaughter and previous history of the animals. J. Anim. Sci. 84:1567-1576.

Mudron, P., J. Rehage, H. P. Sallmann, M. Holtershinken, \& H. Scholz. 2005. Stress response in dairy cows related to blood glucose. Acta Vet. Brno. 74:37-42. http://dx.doi. org/10.2754/avb200574010037

[OIE] Office des International Epizooties. 2008. Slaughter Animals. http://www.oie.int. [31 December 2013].

Okeudo, N. J., \& B. W. Moss. 2005. Serum cortisol concentration in different sex-types and slaughter weights and its relationship with meat quality and intramuscular fatty acid profile. Pakistan J. Nut. 4:64-68. http://dx.doi.org/10.3923/ pjn.2005.64.68
Panea B., C. Sanudo, J. L. Olleta, \& D. Civit. 2008. Effect of ageing method, ageing period, cooking method and sample thickness on beef textural characteristic. Spanish J. Agric. Res. 6:25-32. http://dx.doi.org/10.5424/sjar/2008061-291

Petty, D. B., J. Hattingh, M. F. Ganhao, \& L. Bezeuidenhout. 1994. Factors which affect blood variables of slughetered cattle. Afr. Vet. 65:41-45.

Salakova, A., E. Strakova, V. Valkova, H. Buchtova, \& I. Steinhauserova. 2009. Quality indicators of chicken broiler raw and cooked meat depending on their sex. Acta Vet. Brno. 78:497-504. http://dx.doi.org/10.2754/avb200978030497

Saunders, M., P. Lewis, \& A. Thornhill. 2009. Research methods for business. $5^{\text {th }}$ ed. Prentice Hall, England.

Soeparno. 2005. Meat Science and Technology. Gadjah Mada Univ Pr, Yogyakarta.

Weglarz, A. 2010. Meat quality defined based on $\mathrm{pH}$ and colour depending on cattle category and slaughter season. Czech J. Anim. Sci. 55: 548-556.

Yu L, H., E. S. Lee, J. Y. Jeong, H. D. Paik, J. H. Choi, \& C. J. Kim. 2005. Effects of thawing temperature on the physicochemical properties of pre-rigor frozen chicken breast and leg muscles. Meat Sci. 71:375-382. http://dx.doi.org/10.1016/ j.meatsci.2005.04.020 